\title{
Academic Spin-off as Triple Helix Element: Case-Study of Russian Regions
}

\author{
Konstantin Grasmik
}

\begin{abstract}
The innovation process is becoming more open. According to the concept of the Triple Helix, this requires the creation of institutions capable of mediating the interaction of agents, primarily related to the different elements of the innovation system. The academic spin-off is not only a form of technology transfer, set up at the university but also the institution that provides the interaction of scientists and entrepreneurs. This article gives an analysis of the implementation of the program of creating academic spin-offs in Russia. The main focus of the study is to analyze the affiliation of university spin-off with other companies, including personal links of founders. Research reveals that linkages are substantially personal: University staff member at the same time could be an entrepreneur. This finding allows not only clarifying the concept of the Triple Helix but also increasing the effectiveness of innovation policy, focusing on employees who can combine science and entrepreneurship.
\end{abstract}

Keywords: academic spin-off; innovation; networks; knowledge; region; Triple Helix; regional innovation system; Russia.

Submitted: June 30th 2016 / Approved: September 12th 2016

\section{Introduction}

Academic spin-off became much more important form of technology transfer than a few decades ago. So the quantity of scientific papers devoted to its development continues to rise sharply. But in the first place study of university spin-offs is primarily aimed at the analysis of the factors stimulating their creation (Di Gregorio and Shane, 2003; Landry et al., 2006; Baldini, 2010). Evaluation of their impact on the economic development of the country is mixed. Vincett P.S. (2010) on the example of Canada shows that some spin-offs steadily grow for decades. Expenditures of the state budget allocated for their support are less than subsequent tax revenue. However, in Italy and Japan, the majority of the spin-off is created by young employees and engaged in the provision of consultancy services, rather than the commercialization of technology. These enterprises have low capital stock, volume of sales and number of employees (Etzkowitz et al., 2008; Ramaciotti and Rizzo, 2015). The main function of the spin-off is to ensure technology transfer to the market. With rare exception, they do not have enough resources to compete with incumbents, so cooperation with a larger company is of great importance for them. Some studies describe the positive effect of interaction with existing companies on the development of academic spin-offs (Shane, 2001; Shane and Stuart, 2002). Nevertheless, there is a lack of empirical publications (especially on developing countries) that address the problem of job combination by university researchers: simultaneous work in education, research, and business.

It follows from Triple Helix concept that institutions mediate interaction of subsystems of the innovation system, on the one hand, and ensure communication with the agents that are outside the community, on the other. In our opinion, an academic spin-off is one of such institutions, not just the form of technology transfer. On the one hand, such a company receives support from alma mater, being, in essence, an extension of university laboratories (Etzkowitz, 2003). On the other hand, the key task of the company is the realization of an innovative project that requires developing the technology of product manufacturing, attracting investors, conducting market research, etc. Consequently, the University becomes a part of the business environment, and employees of the university who created this company act as an agent, a link between educational, scientific and entrepreneurial sectors. As the experience of Silicon Valley confirms, in future such personnel increase its importance as a bridge by becoming venture capitalists (Bresnahan et al., 2001; Adams, 2005). Thus, the concept of Triple Helix should be somewhat supplemented: not only institutions but also individuals act as a link between the elements of the innovation system. And the worse the development of supportive organizations, the higher the role of individual agents' networking. Accordingly, the purpose of this article is to analyze the development of the academic spin-off as Triple Helix Institute on the example of Russian university spin-offs. The evaluation of the actual number of spin-offs is carried out because universities could create spin-offs for accountability purpose under the administrative pressure. The emphasis of the research is on spin-off viability by identifying their relationships with entrepreneurial organizations and differences between universities of the same region.

The paper is organized as follows. Sections two and three deal with the theoretical basis of the study. Part four analyzes the legislation governing the creation of academic spin-offs, as well as the results of the implementation ща this state program. Section five discloses a technique of identifying and evaluating the links between spin-offs and other companies. The next part contains the comparative analysis of characteristics of knowledge generation and exploitation subsystems of regional innovation systems. Section seven describes the results of analysis of the spin-off sectors in four regions of Russia. At the end of the paper, findings are discussed.

School of Economics and Management, Far Eastern Federal University, Vladivostok, Russia. E-mail: grasmik.ki@dvfu.ru 


\section{Triple Helix as a tool of economic development}

The concept of Triple Helix is a networking mechanism for the development and implementation of innovation policy within the Triangle University-Business-State. The participants of the innovation process carry out constant coordination, develop the vision of the prospects for the development of industries and technologies. Triple Helix institutes are aimed not only at promoting the development and implementation of innovative projects but also at the creation of communities, networking among economic agents.

The emergence of the Triple Helix is the response to the increase in the scale and pace of technological change and the resulting uncertainty of economic development. The innovation process is becoming more open and nonlinear (Chesbrough, 2011). The company could collaborate with other organizations in R\&D; be engaged in technology exchange; acquire knowledge and ideas from the outside; create a market for its products by providing open access to some patents, etc. The determining factor of success becomes championship in entering the market with a new product and the exploitation of innovation under the framework of a better business model, which requires close agents interaction.

The scope of cooperation and its effectiveness depends on many factors. The important role belongs to geographical proximity of potential participants (Boschma and Ter Wal, 2007). Aside from the substantial reduction of material costs territorial proximity makes it easier to transfer implicit knowledge (Singh, 2005), stimulates the growth of trust due to the increased frequency of interaction and effect of reputation. However, geographical proximity is neither a necessary nor a sufficient condition for the generation and sharing of knowledge (Giuliani and Bell, 2005). Also organizational proximity of agents (work in the same company, the cross-membership in the board of directors, etc.) stimulates the establishment and maintenance of contacts. The next significant factor of cooperation is the social proximity of the participants (Breschi and Lissoni, 2009). Cognitive proximity implies similarity of agents' competencies, which allows them better understand each other (Nooteboom, 1999). It is appropriate to give the following practical example: venture investors often lack the knowledge to understand the meaning and evaluate the perspectives of inventions. Inventors do not have enough market competencies to properly develop business plan (Wright et al., 2007).

Overcoming the lack of proximity is carried out both through the creation of institutions that promote cooperation of economic agents and by the universalization of their activities. For example, in higher education transition of universities to the entrepreneurial university model takes place in many countries. It differs from a research university by integration of entrepreneurship in organizational purposes. In other words, the development of training courses, conducting $\mathrm{R} \& \mathrm{D}$ and publication of its results in top-ranked journals are not an absolute priority for the entrepreneurial organization (Perkmann et al., 2013). The university creates institutions that govern the process of commercialization of innovation (technology transfer offices), stimulate the creation of new businesses (business incubators) and cooperation with existing companies (science parks). The entrepreneurial organization offers seed funding for student projects, university rules on intellectual property do not prevent the commercialization of scientific research results (Moray and Clarysse, 2005). In the process of creating and managing academic spin-off university staff build up a network of contacts in the business community. Thus, not only the formal institutions but also the experienced staff could act as the channel of the university integration into the business environment.

\section{Entrepreneurial experience and its role in spin-off development}

The steady growth of a university spin-off depends on the company's founders, their knowledge, perseverance. Setting up a firm requires a combination of behaviorist models of scientist, engineer, and entrepreneur. The aim of the scientist is to show the new effect, the engineer must develop production technology, the entrepreneur must ensure the availability of necessary resources to develop the effective business model, and organize the process of its implementation. Accordingly, the inventor should possess entrepreneurial characteristics: the presence of organizational skills, leadership skills, willingness to take risks, learning ability, negotiation skills, etc. Gottschalk et al. (2010) confirmed that if founders of spin-off have entrepreneurial or managerial experience, the size of the university spin-off is usually bigger. The coincidence of areas of activity is not a significant factor. Learning curve of entrepreneur affects the probability of conducting research, patenting, innovation exploitation (Cefis, 2003). The experience gained provides insight into consumer needs, technological features of production, characteristics of the labor market, the channels of obtaining financial resources, etc., thus allows focusing of research in commercially attractive areas (Fritsch and Krabel, 2012).

Attraction of investors requires dense and extensive contacts in financial and industrial communities. Some empirical studies (Walter et al., 2006; Miller et al., 2016) show that the ability of researchers to establish strategical relations with industry and end-users increases the chances of successful implementation of the innovative project. The dense network of contacts allows easier estimating of the market potential, developing a strategy for the protection of intellectual property rights, prototyping. An external company could possess a share in the capital of the academic spin-off. As a result, the university spin-off could get from the affiliate company not only knowledge and technology but also material and financial resources (Klepper and Sleeper, 2005). The study by Aggarwal et al. (2004) demonstrated that the acquisition of knowledge through interaction with an industrial partner is more efficient than by hiring of specialists. However, the study by Balderi and Piccaluga (2010) showed that there was an impact of link with another company on the growth rate of spin-off employment, but not on the volume of assets or revenues. A possible explanation could be as follows: academic spin-off just performs the function of the developer of the innovative project for the portfolio of a large company. 


\section{Institutional conditions and academic spin-off sector development in Russia}

In 1996, federal regulations prohibited universities and research institutes to carry out activities not mentioned in the founding documents. Without the consent of the founder (as a rule, the Ministry of Education) University could not transfer the property, including IP, in the capital of the spin-off. Accordingly, the emerging process of cooperation with business slowed down significantly. The process of technology transfer became informal. Because of the low average wage in higher education sector scientists and engineers were forced to do business on their own, but more often interacting with entrepreneurs. As a result, employees of universities used state property to work for affiliated companies. In the context of the unfriendly business environment, the regulative pressure, the high cost of resources, the lack of development of innovation infrastructure in the majority of universities cooperation with other company remains a determining factor for the spin-off development. One of the key reasons for the high importance of the network of contacts with other companies is the lack of state support for spin-offs. The amount of capital required to implement high-tech projects is many times higher than state subsidies. And program to support medium high-tech enterprises is missing.

Practice confirmed that even in such circumstances, university - business cooperation could lead to the creation of medium-sized companies competitive on the global market. The crisis of 2009 provoked a change of policy about the academic spin-off. Right to transfer IP in the capital of the company without the consent of the founder, and, respectively, to create a spin-off Russian universities and research organizations received after the adoption of the Federal Law №217². However, a sharp rise in the number of academic spin-offs did not occur in the first year. The reasons were the discrepancy of the Federal Law №217 to provisions of other legal acts and the absence of sub legislative acts, which would enable academic spin-off to use state benefits. For example, universities did not have right to dispose of its share of spin-off revenues; spin-off could not participate in tenders; spin-off could not get premises and equipment without public procurement procedure, etc.

After resolving of the legal issues there was the sharp increase in the number of academic spin-offs in the second half of 2010. However, for the next years, there is the downward trend in the spin-off creation for the following reasons. At first, before the adoption of the Federal Law, universities could not dispose of income from intellectual property licensing. According to the norms of fiscal legislation, higher education organization had to transfer entire revenue from licensing to the federal budget. Thus, the incentives for registration and maintenance of patents, to the creation of innovative infrastructure, establishment and maintenance of contacts with companies, didn't exist. Employees registered patents for themselves and created firms to commercialize them. Strictly speaking, some of the academic spin-off represents the formalization of relations between universities and companies of their employees. Secondly, the stock of competitive intellectual property is exhausted. The new spin-offs require $R \& D$ and registration of patents, which is quite a long process. Thirdly, the university could not invest a patent or exclusive license in spin-off capital. But the creation of spin-off based on the know-how requires a relationship of trust between the university, inventors, and entrepreneurs. Lastly, the Law №217 requires that the university share in spin-off capital is always at least $34 \%$ (for the joint-stock company - 25\%). It does not allow the higher education organization to attract venture capital investments by reducing its stake, therefore, reduces the incentive for inventors to create spin-off too.

The dense social networks, the availability of entrepreneurial experience significantly affects the development of academic spin-off. Shane S. (2001) showed that the higher the number of business projects implemented by the university researcher, the higher the probability of commercialization of the following patents: 2-3 times compared with the inventors who have no business experience. It is noteworthy that the patent specifications: radicalism, patent scope and scale of the potential use - increases the likelihood of the commercialization of only $3-16 \%$. In Russia, more than 2,900 academic spin-offs were created. An investor has a share in the capital of about $25 \%$ of spin-offs. However, the conclusion about the potential results of such cooperation is difficult to do because spin-off could be affiliated with other companies through personal links of inventors or director as they could be founders in other firms.

\section{Methodological framework}

Objective assessment of the interaction between universities and companies requires an analysis of the largest possible kinds of linkages, as well as taking into account the institutional features of SME. Interorganisational linkages could be formal or informal. An example of a formal cooperation agreement is R\&D contract. However, contracts with spinoff are to a great extent informal in nature since compliance with all formalities (e.g. registration of the tender documents) entails significant transaction costs. Such contracts could be implemented between, say, relatives, former colleagues, etc. They could be difficult in detectability because of the desire to save trade secrets, so the focus of the research is on detectable relations. When institutions are imperfect, transaction costs to protect contractual rights are high, patent commercialization significantly depends on the efforts of management team, participation of key personnel in the company's capital is valuable incentive. Therefore, the object of analysis is the ownership structure of academic spin-off and their affiliated companies. Property rights in Russia are highly personified. It means that the connection between formally independent firms could nevertheless exist through the same founders. It is necessary to separate the cases when the person controls the company or just can participate in management. As well it is important to take into account the total turnover of all the affiliated companies. The source of information about companies is FIRA-PRO database. Accordingly, the algorithm of the research is as follows:

1. To collect the following information on spin-offs: value and structure of capital, industry affiliation of external investors, their turnover (if present), the presence of entrepreneurship experience until 2009 for founders, personal links of spin-off's owners with other companies. 
2. To carry out the search for information on the Internet for each spin-off and its affiliated companies to get a better idea on the scope and scale of its activities.

3. Since the proper quantification of the intensity of contacts has methodological difficulties the next step is to distinguish several types of networking:

- WC (weak connection) - connection exists; however, financial information is absent, or the total annual turnover of affiliated companies is less than ten million RUB or there is no information about affiliated companies on the Internet. The last means that information about the firm with sizable turnover usually is presented mass media.

- MC (medium intensive connection) - the total annual turnover is more than ten million RUB, but the spin-off's founders play a subordinate role in this external company (or they are just affiliated with founders of large firms on other projects).

- PC (powerful connection) - if the owners of an academic spinoff at the same time play a dominant role in the management of companies with a total turnover more than ten million RUB.

To distinguish the weak link from other types threshold value of 10 $\mathrm{mln}$. RUB. (approximately $\$ 0.15 \mathrm{mln}$.) is used. Of course, the minimum level of turnover sufficient to co-finance innovative project is individual and depends on many factors. For example there are sectoral affiliation of the innovation project, amount of investment required, project implementation period, availability of state support, presence of co-investors, guaranteed orders, accumulated wealth of entrepreneurs, real rate of return, etc. As it follows from publications in Russian business press, dedicated to the description of the practice of the implementation of innovative projects, many projects (especially IT) require much less than ten mln. RUB as the initial investment. Also if the project of an academic spin-off requires a significant investment, the prominence of investor clearly indicates on it.

\section{General characteristics of regions}

Despite the fact that according to the Constitution Russia is a federal state, in reality, it is closer to unitary one. Several reasons explaining it are the concentration of tax revenues in the federal budget, the lack of development of tax base in many regions and, as a result, dependence on federal transfers, the exaggerated role of the capital city (Moscow) in the scientific, business, cultural, sports, social and all other spheres. The result of this uneven development is that academic spin-offs are absent in fifteen regions, in twenty four there are less than ten firms. As a rule, these territories have depressed economies, a small number of researchers (less than 300) and in fact absence of regional innovation system.

Regional innovation system consists of two subsystems: the generation and dissemination of knowledge and exploitation of knowledge (Autio, 1998). But as noted by Etzcowitz (2008) the effectiveness of the functioning of the system is increased by the presence of institutions that mediate the interaction of the subjects of the two subsystems. Cooke et al. (1997) argue that the system of norms, rules, and values, organizational structures is formed evolutionary, and its main function is to increase the degree of confidence. For the analysis four regions of Russia were chosen, which are characterized by the presence of a stable and diversified economy and developed knowledge generation sector, namely, St. Petersburg, Krasnodar, Novosibirsk region and Belgorod region (See some indicators in Table 1).

Table 1 - Descriptive statistics of regions

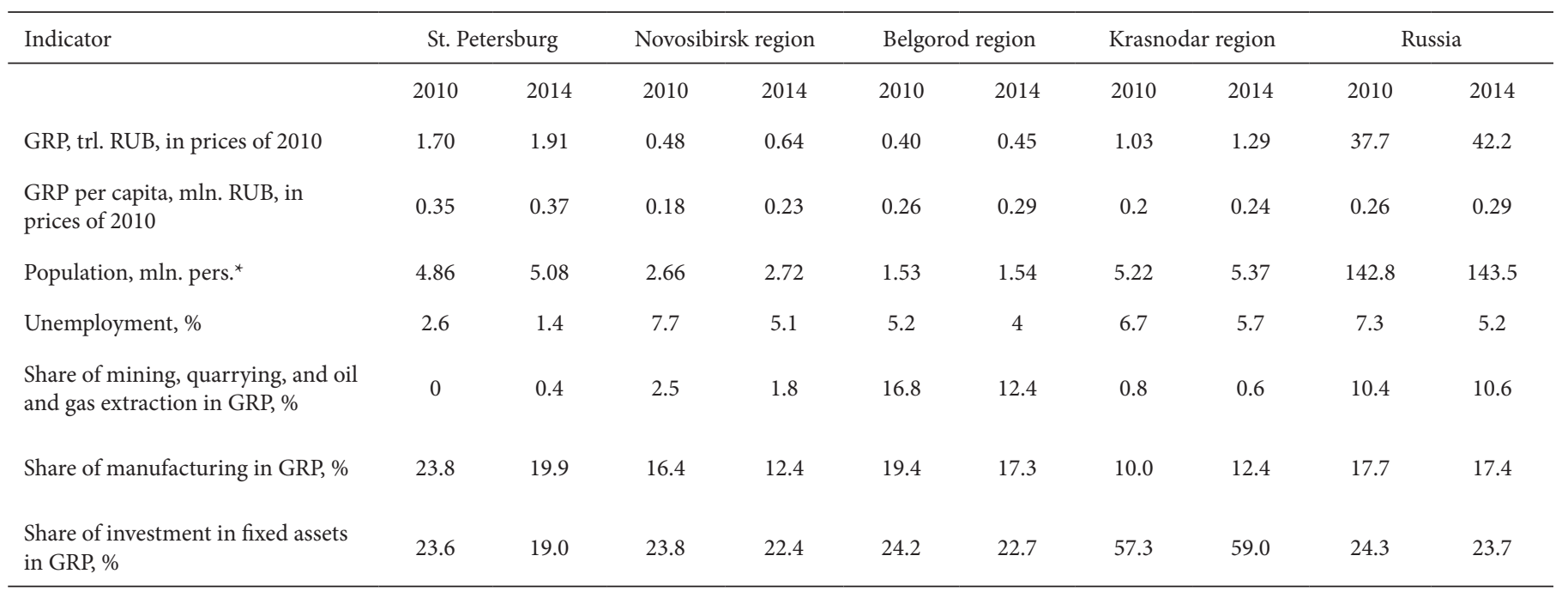

* - data was taken on 2010 and 2013.

Source: Statistical Agency of Russia 
Regions are situated in different parts of Russia: St. Petersburg - in the north west (on the border with Finland), Belgorod region - in central Russia, Novosibirsk - in Siberia, finally, Krasnodar region - in the south. All territories are large, self-sufficient and industrialized. Even in agriculture-oriented Belgorod and Krasnodar share of manufac- turing in the gross regional product is quite high. The mining sector is almost always absent, except Belgorod region. In all regions, the growth rate of GRP per capita exceeds the level in Russia as a whole. The rate of population growth which is higher than in Russia as a whole, also confirms its economic and social competitiveness.

See knowledge-generation subsystem indicators in Table 2.

Table 2 - Knowledge-generation subsystem indicators

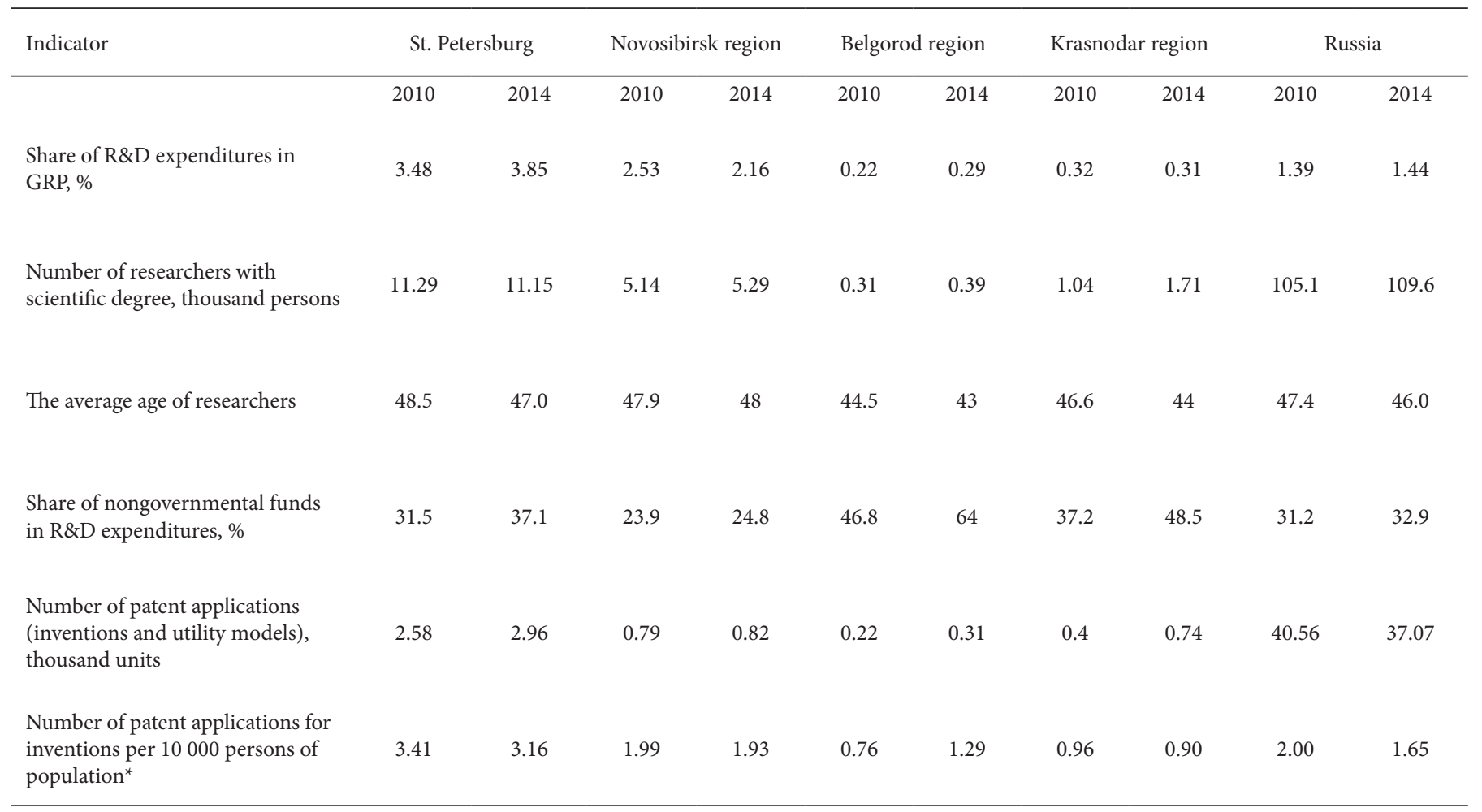

* - data for 2012 and 2014.

Source: Statistical Agency of Russia

A high proportion of R\&D expenditures in GRP in St. Petersburg and Novosibirsk is due to the role of these regions as leading research centers in Russia. However, much of the work performed is fundamental. The share of non-governmental funding is lower than in the other two regions. In all territories except the Novosibirsk region this proportion increased significantly, indicating the growth of interaction between local research institutions and companies. The number of patent applications per researcher is several times higher in Belgorod region and Krasnodar region in comparison with other two territories. As the share of the research sector in Belgorod region and Krasnodar Territory is much less, the number of patents on the invention per 10000 inhabitants is below than in Russia as a whole. Higher migration influences this indicator, but in St. Petersburg in 2014 number of patent applications for inventions was by only 41 more than in 2010. The explosive growth in the number of researchers with scientific degrees in Krasnodar and the stagnation of this indicator in St. Petersburg suggest that scientific activity begins to shift in the more southern regions followed by internal migration. It should be noted the backlog of Novosibirsk region. By all accounts, including the average age of researchers, the region loses. If current trend maintains, the territories will swap in the nearest future. Indicators of innovation activity of regional economies, reflecting the use of knowledge, are presented in Table 3. 
Table 3 - Knowledge-exploitation system indicators

\begin{tabular}{|c|c|c|c|c|c|c|c|c|c|c|}
\hline \multirow[t]{2}{*}{ Indicator } & \multicolumn{2}{|c|}{ St. Petersburg } & \multicolumn{2}{|c|}{ Novosibirsk region } & \multicolumn{2}{|c|}{ Belgorod region } & \multicolumn{2}{|c|}{ Krasnodar region } & \multicolumn{2}{|c|}{ Russia } \\
\hline & 2010 & 2014 & 2010 & 2014 & 2010 & 2014 & 2010 & 2014 & 2010 & 2014 \\
\hline $\begin{array}{l}\text { Share of high-tech } \\
\text { industries in GRP, \%* }\end{array}$ & 29,6 & 31,7 & 25,4 & 23,5 & 9,2 & 10,4 & 12,8 & 14,0 & 19,1 & 19,3 \\
\hline $\begin{array}{l}\text { Innovation performance } \\
\text { of organizations, } \%\end{array}$ & 13.0 & 18.9 & 5.5 & 9.7 & 10.9 & 11.5 & 6.2 & 6.2 & 9.5 & 9.9 \\
\hline $\begin{array}{l}\text { Share of innovation } \\
\text { expenditures in volume } \\
\text { of shipped products, \% }\end{array}$ & 1.23 & 2.93 & 1.78 & 1.76 & 0.94 & 0.86 & 0.46 & 0.89 & 1.56 & 3.00 \\
\hline $\begin{array}{l}\text { Share of innovation } \\
\text { products in volume of } \\
\text { shipped products, } \%\end{array}$ & 8 & 12 & 5.1 & 10 & 2.6 & 4.4 & 1.2 & 1.4 & 4.8 & 8.7 \\
\hline $\begin{array}{l}\text { Share of small } \\
\text { enterprises, executing } \\
\text { technological } \\
\text { innovations, } \%^{* *}\end{array}$ & 7.04 & 9.07 & 6.07 & 8.01 & 1.08 & 6.43 & 2.38 & 0.67 & 4.08 & 4.75 \\
\hline $\begin{array}{l}\text { Labor productivity } \\
\text { index, } 2010=100^{* * *}\end{array}$ & & 110.24 & & 108.60 & & 119.73 & & 113.21 & & 110.33 \\
\hline
\end{tabular}

* - data was taken for 2011 and 2014.

** - data was taken for 2009 and 2013.

$* * *$ - data taken: 2011-2013.

Source: Statistical Agency of Russia

In the regions with a strong research sector (St. Petersburg and Novosibirsk) the share of high-tech industries in GRP is higher too. However, this is due to the establishment of defense enterprises in the Soviet era. While in St. Petersburg there is substantial progress: increasing the relative share of innovation expenditures, the share of high-tech industries in GRP, in Novosibirsk region indicators do not grow or are on the national average. The level of innovation activity in Novosibirsk is lower, as indicated by a lower rate of productivity growth over 2010-13, compared with other territories.

So given set of parameters leads to the next conclusions. St. Petersburg is a region with a large-scale research sector. Regional high-tech companies are on the growth trajectory and receptive to innovation. In Novosibirsk economic growth is accompanied by a decrease of the role of high-tech industries; innovative activity corresponds to average figure; patent activity is very low. Belgorod region is a potential region-leader in the development of high-tech industries. The scale is small, but almost all indicators discussed change (some significantly) in a favorable direction. Particularly impressive is the growth of labor productivity. For Krasnodar region the driving force was the large volume of public investment in the process of preparation for the Olympic Games 2014. Of course, it stimulated the dynamics of economic indicators. Sector of knowledge generation in the region is developing rapidly, but technology use in the economy has an episodic character. The indicators reflecting it are the low share of innovative products in the volume of goods shipped, the low level of innovation activity, weak involvement of small enterprises in the exploitation of knowledge, etc. The affiliation of academic spin-off with business is less in Novosibirsk and Krasnodar region compared to other territories.

\section{The results of the study}

\section{a. Krasnodar: results below expectations}

There are nine universities and eighteen research institutions, located in different parts of the region. Perhaps their specialization in the disciplines related to agriculture stipulates lagging behind, because there are only 29 academic spin-offs in Krasnodar. But five companies are not technology-intensive, concerning OKVED (Russian analog of NAICS). The authorized capital of the regional academic spin-off, as a rule, is more than the minimum size; however, large firms are absent. The size of the authorized capital depends on the university. Also different is its policy about the share in the spin-off capital. Typically, universities prefer to control (51\% and above), except for the Agricultural University and partially Kuban State University. University policy has the impact on the relationship of academic spin-offs with the business community (see Table 4 ).

Table 4 - Distribution of Krasnodar spin-off on the types of relationships with business

\begin{tabular}{lcccc}
\hline Name of university & Powerful & Medium & Weak & Absent \\
\hline $\begin{array}{l}\text { Kuban State Agricultural } \\
\text { University }\end{array}$ & 1 & 1 & 3 & 2 \\
Kuban State Technical & 0 & 1 & 4 & 2 \\
University & & & & \\
Kuban State University & 1 & 1 & 3 & 3 \\
Sochi State University & 0 & 0 & 0 & 2 \\
\hline
\end{tabular}

More than half of the academic spin-offs is in close relations with other companies. However, only in five cases, it is a strong or medium link. In three of the five cases, a person affiliated with the company 
at the same time works at the university on a regular basis. In other words, the relationship between the components of the double helix (university-business) is of personal nature. Three academic spin-offs have strategic investors (pharmaceuticals, engineering, fodder production). In other cases, there are trade companies, which could help to the development of spin-off but mainly financially.

The low quantity of the academic spin-off in Krasnodar region is due to two main reasons. At first, it is the dominance of the agricultural sector in the regional economy. As a result, about half of the spinoff's innovations focuses on this industry. Secondly, it is the lack of development of innovation infrastructure in the province. For example, both business incubators were created recently: in 2009 and 2011 respectively; Technopark was registered only in 2006. Analysis of the regional legislation confirmed the absence of institutions that promote the development of high-tech firms.

\section{b. Belgorod: territory of growth}

In this region academic spin-offs were created by only two local universities: Belgorod State University of Technology (BSTU) and Belgorod State University (BSU). Most BSTU projects focuses on the construction sector, primarily production of building materials. Another part of the projects concentrates on energy saving. The main areas of BSU spin-off activity are medicine, energy, and telecommunications. It is important to note that almost all spin-off projects coincide with the content of intellectual property, the university invested in capital. So, the share of "false" firms is extremely low.

The creation of academic spin-offs in BSTU presumes preserving control. As a rule, the university share is $51 \%$, at least - $50 \%$. BSU has no control over its spin-offs. Authorized capital of all BSTU spin-offs is close to or equal to the minimum, while in Belgorod State University it is above the minimum of 6-12 times. It indicates on the higher evaluation of BSU's assets, transferred to the capital. The differences are significant in spin-off networking too (see Table 5).

Table 5 - Distribution of Belgorod spin-off on the types of relationships with business

\begin{tabular}{lllll}
\hline Name of university & Powerful & Medium & Weak & Absent \\
\hline $\begin{array}{l}\text { Belgorod State } \\
\text { Technical University }\end{array}$ & 1 & 3 & 13 & 35 \\
$\begin{array}{l}\text { Belgorod State } \\
\text { University }\end{array}$ & 9 & 4 & 5 & 6 \\
\hline
\end{tabular}

Only 17 BSTU spin-offs have close networking relations with other firms. In three cases innovative projects were started long before spinoff creation. Therefore, the spin-off is just a legal shell, a means of enhancing growth through participation in federal grants. Six BSU spinoffs have a strategic investor, which is a medium or a big company in the same area of activity. Three spin-offs are under control of the big holding companies, which supply products for ministries and stateowned companies. In five cases of strong and medium networking cofounder combines employment at the university and entrepreneurship.

The higher efficiency of BSU is caused not only by the cutting-edge scientific research or special status of research university status. Uni- versity is very active in cooperation with local companies, federal and regional authorities to obtain co-financing for the implementation of innovative projects, the creation of innovative infrastructure objects. As a result, investments in BSU over the past decade amounted to over 5.5 billion RUB. University made seed investments in three spinoffs and also in attraction research teams in nanotechnology center.

\section{c. Novosibirsk: science or business?}

In Novosibirsk region, the role of state research organizations in the creation and commercialization of research results is higher than anywhere. There are four academic spin-offs in which research institutions are founders. But only Novosibirsk State University (NSU), situated closely to a lot of scientific organizations is inclined to cooperate. As in Belgorod spin-off, networking types vary considerably depending on the institution (see Table 6).

Table 6 - Distribution of Novosibirsk spin-off on the types of relationships with business

\begin{tabular}{lllll}
\hline Name of university & Powerful & Medium & Weak & Absent \\
\hline $\begin{array}{l}\text { Novosibirsk State } \\
\text { Architectural and } \\
\text { Constructional University } \\
\text { (NSACU) }\end{array}$ & 1 & 1 & 0 & 1 \\
$\begin{array}{l}\text { Novosibirsk State } \\
\text { Agricultural University }\end{array}$ & 1 & 2 & 0 & 1 \\
$\begin{array}{l}\text { NSAU) } \\
\text { Novosibirsk State Technical }\end{array}$ & 2 & 1 & 6 & 15 \\
$\begin{array}{l}\text { University (NSTU) } \\
\text { Novosibirsk State }\end{array}$ & 3 & 2 & 3 & 1 \\
$\begin{array}{l}\text { University (NSU) } \\
\text { Others }\end{array}$ & 1 & 0 & 2 & 1 \\
\hline
\end{tabular}

The interrelation between university share in the capital and its size is confirmed again. For example, in NSTU and NSACU half of spinoffs are controlled by the University. NSU adheres to the sufficiency of "blocking stake" policy - only in the case of one spin-off share is equal to $50 \%$. As a result, the size of NSU spin-off capital exceeds the minimum. In two cases, it is more than 1 million RUB.

Perhaps control of the university is due to the fear that in other case the spin-off founders will independently manage grants and other investments on the realization of $\mathrm{R} \& \mathrm{D}$ projects. As a result, many of the projects on creation of spin-off are developed economically poorly. Universities make little effort regarding attraction financial resources for the development of companies.

Twenty-five spin-offs are in networking relations with other firms. In six cases another company is spin-off's founder. However, this is always a local company. Often spin-off director (cofounder) performs a similar role in the company-cofounder. It means that often employees of universities create academic spin-offs. And the revenue of these companies is rather small. In Belgorod region initiative to create an academic spin-off proceeds from the business, so there are a lot of affiliated medium and even big firms. In Novosibirsk region initiators are higher education organizations through their most active employees. In Novosibirsk region founders of nine out of fourteen spin-offs with powerful and medium types of networking simultaneously work 
in the university, in Belgorod region these indicators are seven and seventeen, respectively. The development of spin-off in Novosibirsk has a closed, local oriented nature, largely due to the almost complete lack of regional and municipal support. The analysis of the recipients of subsidies to small businesses showed that university companies are absent among them. Among the residents of the Technopark and business incubator only one spin-off and four firms affiliated with them.

\section{d. Saint-Petersburg: great potential, but episodic success}

In St. Petersburg universities 137 spin-offs were created. This result is insufficient compared to Belgorod region, given that the number of people employed by the higher education organizations of St. Petersburg, as well as the number of universities itself, is higher nine times. Four organizations created seventy spin-offs. The each other university didn't create more than ten companies. See the distribution of spin-offs on networking types in Table 7.

Table 7 - Distribution of St. Petersburg spin-off on the types of relationships with business

\begin{tabular}{lcccc}
\hline Name of university & Powerful & Medium & Weak & Absent \\
\hline $\begin{array}{l}\text { Saint-Petersburg } \\
\text { State University of }\end{array}$ & 7 & 5 & 9 & 10 \\
$\begin{array}{l}\text { IT, Mechanics and } \\
\text { Optics (SSUIMO) }\end{array}$ & & & & \\
$\begin{array}{l}\text { Saint-Petersburg } \\
\text { State Electrotechnical }\end{array}$ & 3 & 5 & 4 & 2 \\
$\begin{array}{l}\text { University (SSEU) } \\
\text { Saint-Petersburg }\end{array}$ & 7 & 1 & 4 & 1 \\
$\begin{array}{l}\text { State Polytechnic } \\
\text { University (SSPU) }\end{array}$ & & & & \\
$\begin{array}{l}\text { Saint-Petersburg } \\
\text { State Forestry }\end{array}$ & 0 & 2 & 1 & 8 \\
$\begin{array}{l}\text { University (SSFU) } \\
\text { Others }\end{array}$ & 17 & 15 & 19 & 17 \\
\hline
\end{tabular}

Interestingly, the distribution of the spin-off on types of networking is the same in a group of leading universities and others; the proportion of spin-off without connections is less than a third in both groups. Therefore, innovation policy in the region doesn't aim at increasing of spin-off quantity just for reporting, or to receive benefits in the future. In many universities spin-offs are absent. Spin-off market potential and the likelihood of the commercialization of the product considerably depend on the scale of the business, affiliated with an academic enterprise. In cases where data were available revenue of affiliated companies are summarized. In twelve cases they exceed one bn. Rub. (15 mln. USD), which is a feature of St. Petersburg as a "northern Russian capital."

More than in half cases (35 of 62 firms) inter-company cooperation is built with the mediation of one of the co-founders, who is at the same time a teacher (employee) of the University. Plus in ten cases this person is a former employee or graduate student. In some cases, the cumulative revenue of such affiliated companies exceeds $100 \mathrm{mi}-$ llion RUB. An employee of the university, as a rule, is the junior partner: his (her) share in the authorized capital rarely exceeds $25 \%$. The dominant owner is often a local entrepreneur with business interests in several areas. For example, one of the spin-offs is linked personally with the subsidiary of JSC "LANIT." This company is the largest Russian system integrator and partner of more than two hundred major world manufacturers of equipment and software. Suffice it to say that the total number of employees is 5,400 people, and its turnover in 2012 exceeded 73 billion RUB 2 .

As in other regions, the leaders in networking are the universities, which possess objects of innovation infrastructure (technoparks, business incubators, TTO) and have a special status (for example, research university), which provides additional financial resources. But the importance of status should not be overestimated: SSPU is not a research university, but almost all the spin-offs closely cooperate with business. These higher education organizations develop the entrepreneurial competence for a long time. For example, SSEU Technopark was established in 2000; first employee's companies appeared in the $1990^{\text {th }}$ and were placed (informally) in the university premises.

\section{Conclusions}

The aim of this article was to characterize the academic spin-off as the institution of the Triple Helix. By creating spin-offs, the university becomes able to obtain the competence for commercialization its patents, to establish useful contacts, to understand the rules of business. The latter is especially important, because as shown by Shane (2001) if inventors possess entrepreneurial experience, it significantly increases the probability of creating a spin-off in the future. In turn, the external company gains access to new knowledge, talented graduates, etc. Under the conditions of underdeveloped state innovation institutions, such networking becomes personified: employee, graduate student (current or former) at the same time performs the role of entrepreneur.

The spin-off from four regions of Russia with a stable, diversified economy is the research sample. The results reveal that the presence of a developed research sector does not guarantee the active involvement of the local universities in the commercialization of knowledge, as well as the affiliation of academic spin-off with business. On the contrary, it may even interfere. Scientists may prefer a relatively independent existence, as the creation of a successful company requires a tremendous amount of time and effort. If there is the possibility of large-scale research at public expense, the grant requires the preparation of articles in peer-reviewed journals. The combination of activities is possible but requires the very efficient team.

If the spin-off is networked with other company, in more than half of the cases the relationship between the university and the business world is personified: the entrepreneur at the same time is an employee of the University (teacher, dean, provost, etc.) or has work experience (graduate student) at the University. Triple Helix concept focuses mainly on institutions as formal structures designed to reduce friction between the sectors. Meanwhile, the prevalence of personification indicates on the dominant role of informal relationships in the Triple Helix system. And only over time, they could be replaced by formal institutions. The prevalence of this type of personalization 
is dependent on the region and the local economy. In a region with more advanced research sector personification is more pronounced. The higher the total turnover of the affiliated companies, the less significant role an inventor plays.

The analysis confirms that even within the same region universities differ in the intensity of networking with business and involvement of scientists in cooperation with companies. Typically, these universities have a special status and included in the government program to improve international competitiveness. Of course, this brings additional state subsidies, which makes them mobilize efforts to improve management efficiency. However, there are universities without the special status, however, effectively creating spin-offs. The more important factor is the experience in the commercialization of university inventions in cooperation with business. Before the adoption of the Federal Law №217 in 2009 some higher education organizations encouraged the creation of academic spin-off by employees, supporting them with university resources. It was a walk on thin ice for the rector but helped retain employees. Therefore, some of the spin-offs could be a reflection of long-standing cooperation, but it is hardly possible to identify it with certainty.

The research has some limitations. There were analyzed only formal relationships of spin-off's cofounders, i.e. through participation in the capital. However, the academic spin-off can be in close cooperative relations with other firm through the cofounder's relative who holds a high position in the company. Relations with firms can exist on an informal basis. In this case, an employee of the university conducts research informally in the interests of the firm. Therefore, the research results indicate the lowest level of the spin-off networking.

\section{References:}

Adams, S. B. (2005). Stanford and Silicon Valley: Lessons on becoming a high-tech region. California management review, 48(1), 29-51. http://dx.doi.org/10.2307/41166326

Aggarwal, R., Echambadi, R., Franco, A.M., \& Sarkar, M.B. (2004). Knowledge Transfer Through Inheritance: Spin-out Generation, development and survival. Academy of Management Journal, 47(4), 501522. http://dx.doi.org/10.2307/20159599

Autio, E. (1998). Evaluation of RTD in regional system of innovation. European Planning Studies, 6(2), 131-140. http://dx.doi. org/10.1080/09654319808720451

Balderi, C., \& Piccaluga, A. (2010, May 24). A theoretical and empirical contribution for a better understanding of academic spin-offs' growth patterns, MAIN Working Paper 04/2010, Italy. Retrieved from http://ideas.repec.org/p/sse/wpaper/201004.html.

Baldini, N. (2010). University spin-offs and their environment. Technology Analysis \& Strategic Management, 22 (8), 859-876. http:// dx.doi.org/10.1080/09537325.2010.520470.
Boschma, R.A., \& Ter Wal, A.L.J. (2007). Knowledge networks and innovative performance in industrial districts: the case of a footwear district in the South Italy. Industry and innovation, 2, 177-199. http:// dx.doi.org/10.1080/13662710701253441

Breschi, S., \& Lissoni, F. (2009). Mobility of skilled workers and coinvention networks: an anatomy of localized knowledge flows. Journal of Economic Geography, 9(4), 439-468. http://dx.doi.org/10.1093/ jeg/lbp008

Bresnahan T., Gambardella A., \& Saxenian, A. (2001). 'Old economy' inputs for 'New Economy' outcomes: cluster formation in the New Silicon Valleys. Industrial and Corporate Change, 10(4), 835-860. http:// dx.doi.org/10.1093/icc/10.4.835

Chesbrough, H. (2011). Bringing open innovation to services. MIT Sloan Management Review, 52, 85-91.

Clarysse, B, Wright, M., \& Van de Velde, E. (2011). Entrepreneurial Origin, Technological Knowledge, and the Growth of Spin-Off Companies. Journal of Management Studies, 48, 1420-1442. http://dx.doi. org/10.1111/j.1467-6486.2010.00991.x

Cooke, P. Uranga, M. G., \& Etxebarria, G. (1997). Regional innovation systems: Institutional and organizational dimensions. Research Policy, 26(4-5), 475-491. http://dx.doi.org/10.1016/s0048-7333(97)00025-5

Di Gregorio, D., \& Shane, S. (2003). Why do some universities generate more start-ups than others? Research Policy, 32, 209-227. http:// dx.doi.org/10.1016/S0048-7333(02)00097-5.

Etzkowitz, H. (2003). Research groups as "quasi-firms": the invention of the entrepreneurial university. Research Policy, 32, 109-121. http:// dx.doi.org/10.1016/s0048-7333(02)00009-4

Etzkowitz, H., Ranga, M., Benner, M., Guaranys, L., Maculan, A., \& Kneller, R. (2008). Pathways to the entrepreneurial university: towards a global convergence. Science and Public Policy, 35 (9), 681695. http://dx.doi.org/10.3152/030234208X389701.

Fritsch, M. and Krabel, S. (2012). Ready to leave the ivory tower? Academic scientists' appeal to work in the private sector, The Journal of Technology Transfer, 37(3), 271-296. http://dx.doi.org/10.1007/ s10961-010-9174-7.

Giuliani, E., \& Bell, M. (2005). The micro-determinants of mesolevel learning and innovation: Evidence from a Chilean wine cluster, Research Policy, 34(1), 47-68. http://dx.doi.org/10.1016/j.respol.2004.10.008.

Gottschalk, S., Müller, K., \& Niefert, M. (2010). Founder's human capital, entry strategies and start-up size. International Journal of Entrepreneurship and Small Business, 11(4), 403-423. http://dx.doi. org/10.1504/ijesb.2010.036294 
Klepper, S. and Sleeper, S. (2005). Entry by spinoffs, Management Science, Vol. 51 No. 8, pp. 1291-1306. http://dx.doi.org/10.1287/ mnsc. 1050.0411 .

Landry, R., Amara N., \& Rherrad, I. (2006). Why are some university researchers more likely to create spin-offs than others? Evidence from Canadian universities. Research Policy, 17(35), 1599-1615. http:// dx.doi.org/10.1016/j.respol.2006.09.020

Miller, K., Mcadam, R., Moffett, S., \& Puthussery, P. (2016). Knowledge Transfer in Quadruple Helix Ecosystems: An Absorptive Capacity Perspective. R\&D Management, 46(2), 383-399. http://dx.doi. org/10.1111/radm.12182.

Moray, N., \& Clarysse, B. (2005). Institutional Change and Resource Endowments to Science-Based Entrepreneurial Firms. Research Policy, 34(7), 1010-1027. http://dx.doi.org/10.1016/j.respol.2005.05.016

Nooteboom, B. (1999). Innovation, learning and industrial organization. Cambridge Journal of Economics, 23, 127-150. http://dx.doi. org/10.1093/cje/23.2.127

Perkmann, M., Tartari, V., McKelvey, M., Autio, E., Brostrom, A., D’Este, P., Fini, R., Geuna, A., Grimaldi, R., Hughes, A., Krabel, S., Kitson, M., Llerena, P., Lissoni, F., Salter, A., \& Sobrero, M. (2013). Academic engagement and commercialization: A review of the literature on university-industry relations. Research Policy, 42(2), 423-442. http://dx.doi.org/10.1016/j.respol.2012.09.007.

Ramaciotti, L., \& Rizzo, U. (2015). The determinants of academic spin-off creation by Italian Universities. R\&D Management, 45(5), 501-514. http://dx.doi.org/10.1111/radm.12105

Shane, S. (2001). Technological Opportunities and New Firm Creation. Management Science, 47(2), 205-220. http://dx.doi.org/10.1287/ mnsc.47.2.205.9837
Shane, S., \& Stuart T. (2002). Organizational endowments and the performance of university start-ups. Management Science, 48(1), 154170. http://dx.doi.org/10.1287/mnsc.48.1.154.14280

Singh, J. (2005). Collaborative networks as determinants of knowledge diffusion patterns. Management Science, 5, 756-770. http://dx.doi. org/10.1287/mnsc.1040.0349.

Vincett, P.S. (2010). The economic impacts of academic spin-off companies, and their implications for public policy. Research Policy, 39, 736-747. http://dx.doi.org/10.1016/j.respol.2010.02.001.

Walter, A., Auer, M., \& Ritter, T. (2006). The impact of network capabilities and entrepreneurial orientation on university spin-off performance. Journal of Business Venturing, 21(4), 541-567. http://dx.doi. org/10.1007/978-3-8349-8929-1_2

Wright, M., Hmieleski, K. M., Siegel, D. S., \& Ensley, M. D. (2007). The role of human capital in technological entrepreneurship. Entrepreneurship Theory and Practice, 31(6), pp. 791-806. http://dx.doi. org/10.1111/j.1540-6520.2007.00202.x

\section{Footnotes:}

1. Federal Law №217-FZ, 02.08.2009. “On amendments to certain legislative acts of the Russian Federation on the establishment of business entities by budgetary and educational institutions with a purpose of practical application (implementation) of intellectual property".

2. Web-page of JSC "Lanit". http://www.lanit.ru/about. (Accessed 25 March 2016). 